\title{
Rancang Bangun Alat Dryer Untuk Pengeringan Pulp Berbasis Campuran Tandan Kosong Kelapa Sawit Dan Pelepah Pisang
}

\author{
M. Ridho Triadi*1, M. Yerizam² ${ }^{2}$, Selastia Yulianti ${ }^{3}$ \\ ${ }^{1,2,3}$ Program Studi Teknologi Kimia Industri, Jurusan Teknik Kimia \\ Politeknik Negeri Sriwijaya, Indonesia \\ Email: 1ridhoth17@gmail.com, ${ }^{2}$ yerizam@polsri.ac.id, ${ }^{3}$ selastiayuliati@yahoo.com
}

\begin{abstract}
Abstrak
Penggunaan campuran tandan kosong kelapa sawit (TKKS) dan pelepah pisang sebagai bahan pengganti kayu dalam pembuatan pulp menjadi solusi atas kerusakan lingkungan akibat meluasnya penebangan hutan secara liar guna memenuhi bahan baku pembuatan kertas. Dalam pembuatan pulp pada usaha kecil menengah (UKM) masih ditemukan permasalahan dimana proses pengeringan pulp masih mengunakan cara konfensional sehingga memakan waktu yang lama, pengeringan tidak merata, dan bergantung pada cuaca. Hal tersebut yang melatar belakangi penulis melakukan sebuah penelitian dengan tujuan memperoleh satu unit alat dryer tipe tray pada proses pembuatan pulp dari campuran TKKS dan pelepah pisang, serta mendapatkan kondisi optimum dari dryer berdasarkan waktu dan laju pengeringan pulp yang diharapkan memenuhi standar SNI kadar air pulp. Penelitian ini menggunakan metode rancang bangun dan eksperimen. Metode rancang bangun dilakukan untuk perancangan alat pengering tipe tray pada pengeringan pulp. Metode eksperimen dilakukan untuk mendapatkan data kinerja dryer yang ditinjau dari waktu dan laju pengeringan. Hasil dari penelitian ini yaitu didapat sebuah alat Dryer tipe Tray dengan panjang 34,5 cm, lebar $35 \mathrm{~cm}$ dan tinggi 39,5 cm dengan kapasitas maksimal $42 \mathrm{~kg}$. didapatkan pulp dengan kadar air yang sesuai SNI kadar air pulp yaitu sebesar 9,1\% pada waktu pengeringan selama 420 menit dengan laju pengeringan total sebesar $0,012656 \mathrm{~kg} / \mathrm{jam} \mathrm{m} \mathrm{m}^{2}$
\end{abstract}

Kata kunci: pelepah pisang, pulp, TKKS, tray dryer

\section{Design And Construction Of Dryer Tool For Pulp Drying Based On A Mixture Empty Fruit Bunches Oil Palm And Banana Midrib}

\begin{abstract}
The use of a mixture of empty fruit bunches oil palm (EFBOP) and banana midrib as a substitute for wood in the manufacture of pulp is a solution to environmental damage due to widespread illegal logging to meet the raw material for making paper. In the manufacture of pulp in SMEs, there are still problems where the pulp drying process still uses conventional methods so that it takes a long time, drying is uneven, and depends on the weather. This is the background of the author conducting a study with the aim of obtaining a tray dryer unit in the pulping process from a mixture of EFBOP and banana midrib, and to obtain the optimum condition of the dryer based on the time and rate of drying of the pulp which is expected to meet the SNI standard for pulp moisture content. This study uses design and experimental methods. The design method is used to design a tray type dryer for pulp drying. The experimental method was carried out to obtain dryer performance data in terms of drying time and rate. The results of this study were obtained a Tray type Dryer with a length of $34.5 \mathrm{~cm}, a$ width of $35 \mathrm{~cm}$ and a height of $39.5 \mathrm{~cm}$ with a maximum capacity of $42 \mathrm{~kg}$. obtained pulp with a moisture content according to SNI pulp moisture content of $9.1 \%$ at a drying time of 420 minutes with a total drying rate of $0.012656 \mathrm{~kg} /$ hour $\mathrm{m}^{2}$
\end{abstract}

Keywords: banana midrib, EFBOP, pulp, tray dryer

\section{PENDAHULUAN}

Peningkatan akan kebutuhan kertas berbahan dasar kayu dapat menimbulkan dampak negatif terhadap lingkungan. Hal ini berakibat penebangan hutan menjadi semakin meluas. Selain itu proses pulping yang dilakukan masih menggunakan bahan kimia yang susah untuk didegradasi secara alami. Salah satu cara alternatif dalam mengurangi efek negatif ini yaitu dengan menggunakan bahan nonkayu sebagai bahan baku utama dalam pembuatan pulp[1]. 
Tandan Kosong Kelapa Sawit (TKKS) merupakan limbah padat yang dihasilkan oleh industri pengolahan minyak kelapa sawit. Untuk Saat ini, Pemanfaatan TKKS pada saat ini masih sangat sedikit dan nilai ekonominya tergolong sangat rendah [2]. Kandungan selulosa pada limbah TKKS ini yang berpotensi tinggi untuk dimanfaatkan sebagai bahan baku pembuatan pulp. Maka, salah satu solusinya adalah dengan memanfaatkan TKKS tersebut sebagai alternatif bahan baku pembuatan pulp kertas.

Pelepah pisang merupakan bagian dari tanaman pisang yang kurang dimanfaatkan oleh masyarakat. Biasanya batang pisang dibuang dan dibakar, yang dapat menyebabkan sampah menumpuk [3]. Pelepah pisang mempunyai kandungan selulosa yang tinggi akan tetapi belum dimanfaatkan secara optimal [4]. Pelepah pisang di masyarakat hanya dijadikan limbah yang tidak dipergunakan, kandungan selulosa pada pelepah pisang cukup besar, sehingga dapat digunakan sebagai komponen utama campuran pulp [5].

Dalam kajian Fariati [6] yang telah melakukan pembuatan pulp berbahan dasar campuran TKKS dan pelepah pisang dengan perbandingan larutan pemasak yaitu 2 : 1 : 5. Pada temperatur pemasakan $120^{\circ} \mathrm{C}$ didapatkan waktu optimum, pada waktu 150 menit dengan hasil \% selulosa sebesar 47,14 dan \% rendemen sebesar $45,57 \%$.

Tahap akhir dalam proses pembuatan pulp yaitu pengeringan. Pengeringan merupakan suatu metode untuk menghilangkan sebagian air dari material dengan cara menguapkan sebagian besar air yang terkandung dalam panas penguapan [7]. Pengeringan pulp yang saat ini dilakukan sebagian besar UKM masih bersifat manual (konvensional) yaitu menggunakan tenaga matahari atau menjemur di bawah sinar matahari sehingga memakan waktu lama dan proses pengeringan yang tidak merata, pengeringan konvensional ini juga sangat tergantung pada kondisi cuaca di sekitarnya [8].

Berdasarkan permasalahan yang terjadi, maka dari itu diperlukannya suatu alat pengering yang bertujuan untuk membantu pada proses pengeringan pulp. Salah satu metode pengeringan yang dapat digunakan dalam mengeringkan pulp yaitu dengan bantuan alat tray dryer. Tray dryer dapat digunakan untuk mengeringkan bahan yang berupa padatan atau padatan kental (seperti pasta), dimana bahan tersebut didistribusikan secara merata pada rak pengering [9].

Berdasarkan penilitian sebelumnya yang telah dilakukan tentang kajian pengeringan pada alat tray dryer salah satunya yaitu Kurnia [10] telah melakukan kajian tentang pengeringan chip ubi jalar kuning dengan menggunakan Tray Dryer dengan laju pengeringan $0,084 \mathrm{~kg} / \mathrm{jam} \cdot \mathrm{m}^{2}$ pada temperatur $50^{\circ} \mathrm{C}$ dan $0,005 \mathrm{~kg} / \mathrm{jam} \cdot \mathrm{m}^{2}$ pada temperatur $60^{\circ} \mathrm{C}$ dan Makaminan [11] juga telah melakukan kajian dengan menggunakan alat tray dryer untuk menentukan waktu dan laju pengeringan dalam pembuatan silica gel berbasis ampas tebu dengan kadar air sebesar $0,814 \%$ dan laju pengeringan sebesar $0,01941 \mathrm{~kg} / \mathrm{jam}$.

Penelitian ini diharapkan dapat memberikan manfaat Bagi Ilmu Pengetahuan dan Teknologi (IPTEK), dimana penelitian ini menjadi acuan pengembangan Ilmu Pengetahuan dan Teknologi (IPTEK) dibidang pembuatan pulp menggunakan campuran TKKS dan pelepah pisang, khususnya teknologi alat dryer. Penelitian ini juga diharapkan dapat memberikan manfaat bagi masyarakat tentang pengetahuan mengenai proses pengeringan dryer yang dapat digunakan untuk pengeringan pulp dari campuran TKKS dan pelepah pisang sehingga dapat memenuhi standar kadar air pulp [12]. Selain itu, penelitian ini juga diharapkan dapat bermanfaat bagi Lembaga Akademik (Politeknik Negeri Sriwijaya) untuk digunakan sebagai bahan riset untuk dosen dan mahasiswa serta pembelajaran di laboratorium.

Untuk mengetahui kecepatan pengeringan maka perlu diketahui laju pengeringan dari bahan. Laju pengeringan merupakan besarnya jumlah air yang diuapkan persatuan waktu atau perubahan kadar air bahan dalam satu satuan waktu. Laju pengeringan yang tinggi didapatkan dari besarnya suhu dan kelembaban relatif tertentu dengan kecepatan aliran udara pada permukaan bahan yang cukup sehingga proses perpindahan panas dari udara ke bahan berlangsung baik.

Laju pengeringan konstan Rc, dapat dihitung dengan menggunakan rumus pada persamaan 1 dan 2 .

$$
\begin{aligned}
& X t=\frac{W-W s}{W s} \\
& \mathrm{Xt}=\text { moisture content basis kering } \\
& \mathrm{W}=\text { berat bahan basah }(\mathrm{kg}) \\
& \mathrm{Ws}=\text { berat bahan kering }(\mathrm{kg}) \\
& R=-\frac{W s \cdot d X t}{A \cdot d t} \\
& \mathrm{R}=\text { laju pengeringan }\left(\mathrm{kg} \mathrm{H} 2 \mathrm{O} \text { yang diuapkan } / \mathrm{jam} \cdot \mathrm{m}^{2}\right) \\
& \mathrm{Ws}=\text { berat bahan kering }(\mathrm{kg}) \\
& \mathrm{A}=\text { luas permukaan bahan }\left(\mathrm{m}^{2}\right)
\end{aligned}
$$


$\mathrm{Xt}=$ moisture content basis kering $\left(\mathrm{kg} \mathrm{H} \mathrm{H}_{2} \mathrm{O} / \mathrm{kg}\right.$ bahan kering)

$\mathrm{T}=$ waktu (jam)

\section{METODE PENELITIAN}

\subsection{Rancangan Penelitian}

Penelitian ini menggunakan metode rancang bangun dan eksperimen. Metode rancang bangun dilakukan untuk perancangan alat pengering tipe tray pada pengeringan pulp. Metode eksperimen dilakukan untuk pengujian kinerja dryer untuk mengetahui kinerja alat pembuatan pulp yang ditinjau dari waktu dan laju pengeringan pada dryer. Rancangan alat pembuatan pulp yang terdiri dari alat digester dan alat pengering tipe tray dapat dilihat pada Gambar 1 .

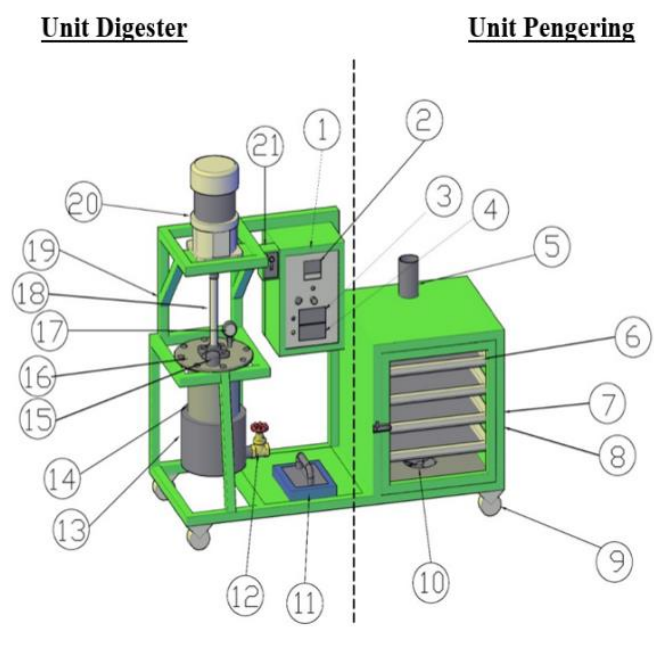

Gambar 1. Rancangan Alat Pembuatan Pulp

Keterangan:

1. Control Panel

2. Display Temperatur Digester

3. Display Kecepatan Pengaduk

4. Display Temperatur Tray Dryer

5. Cerobong Udara Output

6. Rak Pengering

7. Strip Heater

8. Thermocouple

9. Roda

10. Fan

11. Press
12. Valve Output

13. Thermocouple

14. Band Heater

15. Penutup Input

16. Digester

17. Pengaduk

18. Pressure Gauge

19. Kerangka Alat

20. Motor Pengaduk

21. Pengatur Pengaduk

\subsection{Waktu dan Tempat}

Pelaksanaan perancangan alat dilakukan pada bulan April 2021 s.d. Mei 2021, sedangkan penelitian pengeringan pulp dilakukan pada bulan Juli 2021 di Laboratorium Pilot Plant dan Mikrobiologi Jurusan Teknik Kimia Politeknik Negeri Sriwijaya.

\subsection{Perlakuan dan Analisis Statisktik Sederhana}

Untuk pengujian kinerja alat pengering tipe tray, variabel-variabel yang diamati, yaitu variabel bebas, variabel kontrol dan variabel terikat.

1. Variabel bebas

a. Waktu pengeringan 30, 60, 90, 120, 150, 180,210, 240, 270, 300, 330, 360, 390, dan 420 menit.

2. Variabel kontrol

a. Temperatur pengeringan : $60^{\circ} \mathrm{C}$ 
b. bahan baku : Pulp berbasis campuran tandan kosong kelapa sawit (TKKS) dan pelepah pisang),

c. massa pulp : 100 gram,

d. rasio pulp : Perbandingan TKKS dan pelepah pisang yaitu 1:2), temperatur pemasakan $\left(120^{\circ} \mathrm{C}\right)$, waktu pemasakan (120 menit), dan konsentrasi pelarut $\mathrm{NaOH}(9 \%)$.

3. variabel terikat pada pengujian kinerja alat pengering tipe tray ini adalah kadar air pulp.

\subsection{Prosedur Percobaan}

Prosedur percobaan dalam perancangan pengering tipe tray meliputi:

1. Perakitan Alat Pengering Tipe Tray

2. Preparasi Sampel Pulp

3. Pengujian Alat Pengering Tipe Tray (Pengeringan pulp)

4. Pengujian Kadar Air (Metode Oven SNI No. 08-7070-2005) [13]

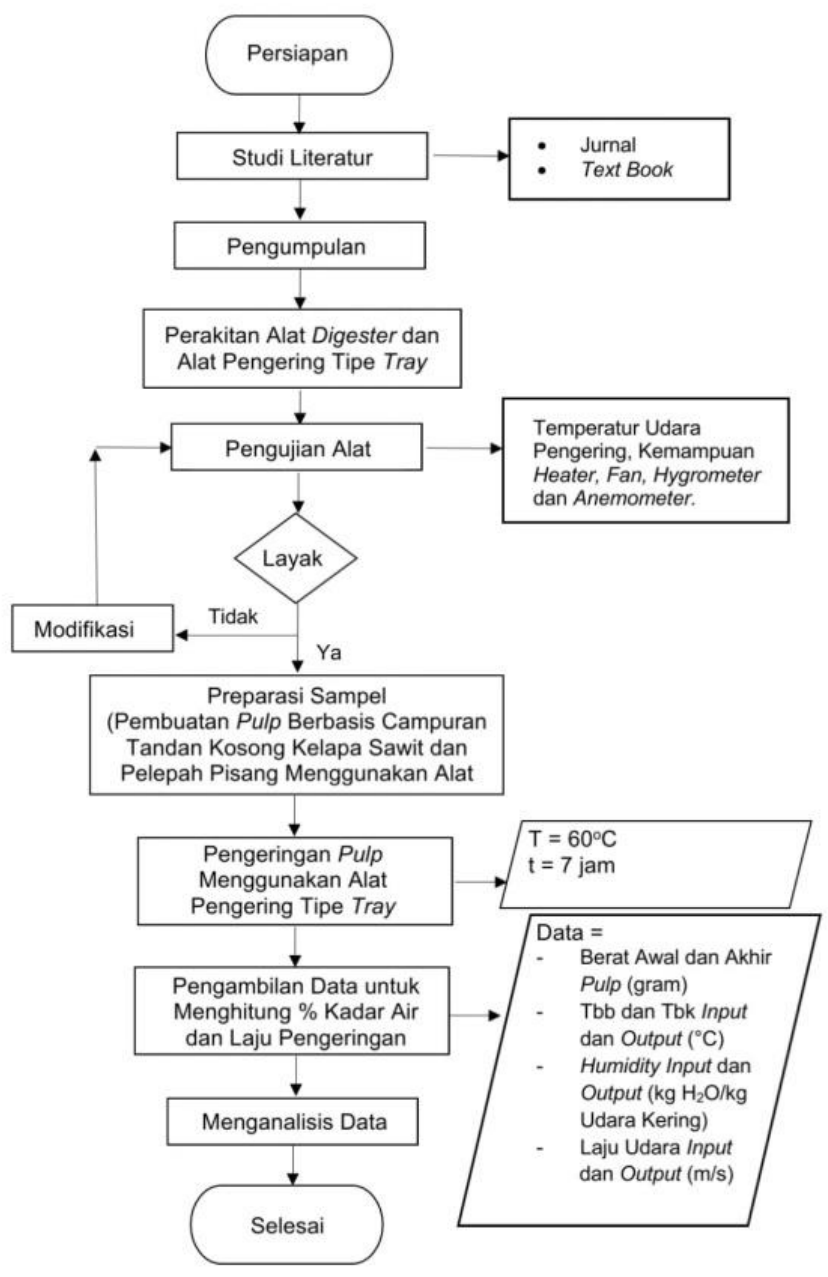

Gambar 2. Diagram Alir Perancangan dan Pengujian Alat Pengering Tipe Tray

\section{HASIL DAN PEMBAHASAN}

Tray dryer atau alat pengering tipe rak, memiliki bentuk persegi dan didalamnya berisi rak-rak, yang digunakan sebagai tempat bahan yang akan dikeringkan. Pada umumnya rak tidak dapat dikeluarkan. Beberapa alat pengering jenis ini rak-raknya memiliki roda sehingga dapat dikeluarkan dari alat pengeringnya. Bahan diletakkan diatas rak (Tray) yang terbuat dari logam yang berlubang. Kegunaan lubang-lubang tersebut untuk mengalirkan udara panas.

Sistem pemanasan pada pengering ini secara tidak langsung dengan memanfatkan udara lingkungan yang dihisap fan. Kemudian, udara tersebut akan dilewatkan pada ruang yang terdapat koil pemanas kemudian udara panas akan dihembuskan pada Tray Dryer. Sistem pemanasan secara tidak langsung dapat mencegah terjadinya 
kontak langsung yang akan mengakibatkan rusaknya pulp. Pemanas yang digunakan merupakan pemanas koil jenis Strip Heater yang memiliki panas maksimum sebesar $200^{\circ} \mathrm{C}$.

Tujuan dari proses pengeringan ini adalah untuk mengetahui kondisi optimum tray dryer dalam mengeringkan pulp yang diharapkan dapat mencapai kadar air $7 \%$ berdasarkan standar kadar air pulp. Berat pulp yang dikeringkan pada penelitian ini adalah 100 gram dengan proses pengeringan selama 420 menit dengan suhu $60^{\circ} \mathrm{C}$. Data hasil penelitian diarahkan untuk dapat melihat Laju Pengeringan pada proses pengeringan tiap rak selama proses waktu 420 menit, sehingga dalam penelitian ini diperlukan analisa secara spesifik mengenai laju pengeringan.

Tray Dryer atau alat pengering tipe rak yang dilengkapi thermocouple sebagai alat pengontrol panas sehingga, proses perpidahan panas yang terjadi akan effisien. Proses pengeringan dibantu juga oleh fan yang berguna untuk mengalirkan udara panas dalam ruang pengering agar terjadi proses pengeringan dengan cepat. Udara panas yang dihembuskan akan masuk ke celah-celah alat sehingga panas akan cepat merambat dan mengurangi kadar air dari pulp. Sumber panas yang disuplai dari stripe heater dimanfaatkan secara optimal untuk menguapkan air dari bahan.

\subsection{Pengaruh Waktu Pengeringan terhadap Kadar Air}

Pengeringan merupakan salah satu cara mengurangi kadar air dalam bahan padat dengan metod penguapan, pengehembuasan ataupun pemanasan pada suhu tinggi, baik dalam tekanan normal maupun vakum [14]. Kadar air suatu bahan berpengaruh terhadap banyaknya air yang diuapkan dan lamanya proses pengeringan [15]. Kadar air suatu bahan menunjukkan jumlah air yang dikandung didalam bahan tersebut, baik berupa air bebas maupun air terikat [16]. Selama proses pengeringan, kadar air bahan mengalami penurunan, besarnya penurunan kadar air bahan tersebut berbeda-beda sesuai dengan banyaknya air yang diuapkan. Pada saat awal proses pengeringan terjadi penguapan air bebas dan penguapan selanjutnya terjadi pada air terikat.

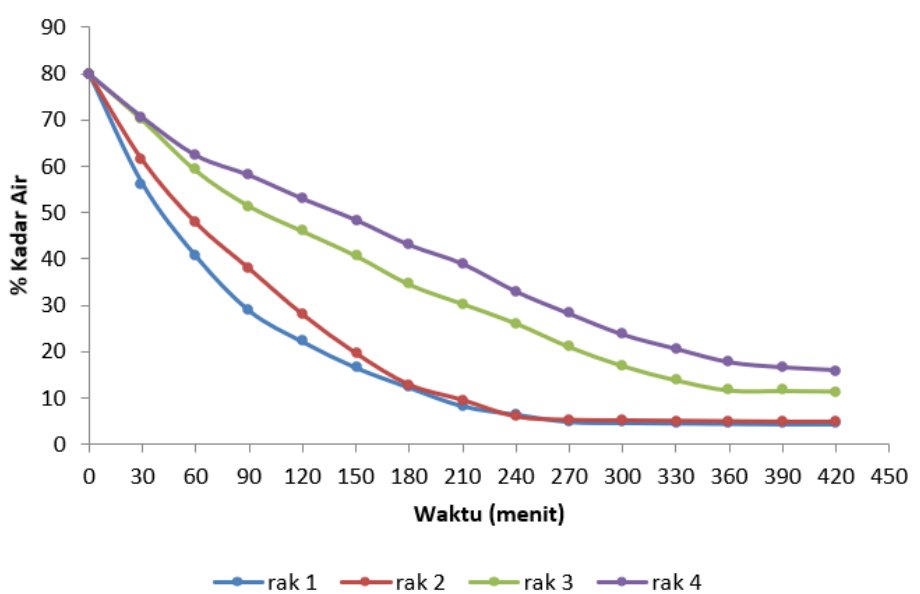

Gambar 3. Pengaruh Waktu Pengeringan terhadap Kadar Air Pulp Tiap Rak

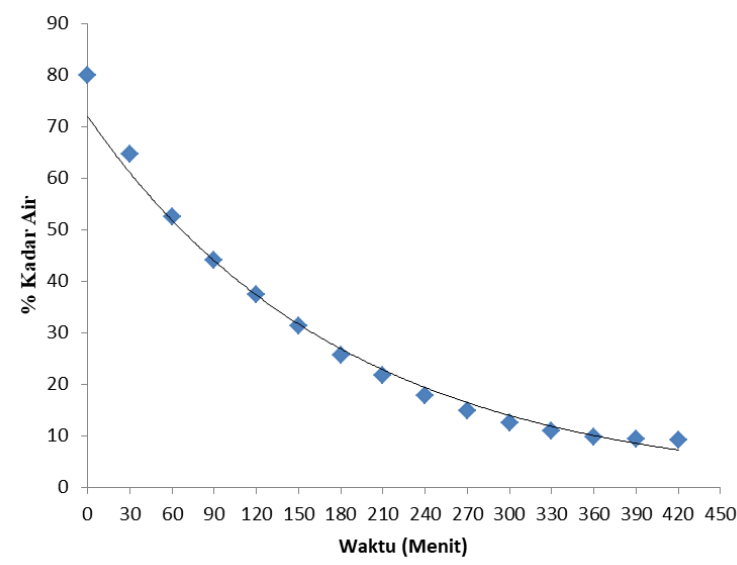

Gambar 4. Pengaruh Waktu Pengeringan terhadap Kadar Air yang Teruapkan 
Kandungan kadar air pulp pada waktu awal pengeringan yaitu sebesar $80 \%$. Selama proses pengeringan, kadar air setiap rak mengalami penurunan kadar air berbeda-beda. Pada gambar 3 dapat dilihat bahwa pada rak ke-1 telah mencapai kadar air sebesar 6,5\% pada waktu 240 menit dan telah mencapai standar kadar air pulp yaitu $\leq 12 \%$, Kadar air masih berkurang secara perlahan pada waktu 270 menit sampai 420 menit dengan hasil akhir kadar air sebesar 4,4\%. Demikian pula pada rak ke-2, proses pengeringan pulp mencapai kadar air standar pada waktu 340 menit dengan kadar air sebesar 5,9\%. Sedangkan untuk rak ke-3 mencapai kadar air standar pada waktu 420 menit dengan kadar air sebesar 11,4\% dan pada rak ke 4 sebesar 15,9\% hal ini berarti bahwa kadar air diwaktu 420 menit pada rak 4 belum mencapai kadar air standar dan masih terjadi proses pengeringan berlanjut. Berdasarkan data yang ada dapat diketahui bahwa semakin lama proses pengeringan terjadi, maka akan semakin kecil pula penurunan kadar air yang terjadi saat pengeringan yang dilakukan pada tray dryer. Perbedaan kadar air setiap rak ini disebabkan oleh panas yang dihasilkan oleh media pemanas terkontak langsung pada rak 1, sehingga energi panas yang dihasilkan terserap terlebih dahulu dan menyebabkan energi panas yang dihasilkan sudah berkurang ketika perpindahan panas terjadi pada rak 2, 3, dan 4. Dapat disimpulkan bahwa semakin jauh rak dari media pemanas, maka energi panas yang diberikan semakin berkurang, sehingga hal ini yang menyebabkan perbedaan kadar air disetiap rak.

Dalam proses pengeringan kadar air menentukan batas akhir dari suatu pengeringan. Pada saat kadar air seimbang, penguapan air pada bahan akan terhenti dan jumlah molekul-molekul air yang akan diuapkan sama dengan jumlah molekul yang diserap oleh permukaan bahan. Pada Gambar 4.2 menunjukkan bahwa hasil penurunan kadar air pulp rata-rata pada waktu 420 menit sebesar 9,1\% < 12\% dengan kadar air pulp yang sesuai standar SNI 6106:2016, tray dryer yang digunakan mampu mengeringkan pulp dengan total kadar air yang teruapkan mencapai 70,9\%, kadar air pulp mengalami pengurangan yang signifikan yang disebabkan karena mula-mula penguapan air terjadi pada permukaan, selanjutnya kadar air pulp mengalami penurunan secara perlahan hal tersebut disebabkan karena air yang ada didalam ruang pengering sudah mulai terjadi pengaliran keluar permukaan [17]. Hal ini sejalan dengan hasil penelitian Makaminan [11] yang melaporkan bahwa semakin lama waktu pengeringan kadar air akan menurun, menyebabkan penguapan air lebih banyak sehingga kadar air dalam bahan akan mendekati standar.

\subsection{Pengaruh Laju Pengeringan terhadap Waktu}

Pada peristiwa pengeringan, air yang diuapkan terdiri dari air bebas dan air terikat. Laju pengeringan sangat tinggi terjadi diawal pengeringan. Hal ini disebabkan banyak kandungan air yang terdapat dalam pulp . Sedangkan dengan bertambahnya waktu dan semakin keringnya bahan, yang tersisa adalah air terikat pada selsel bahan sehingga penurunan kadar air bahan semakin kecil dan konstan [18].

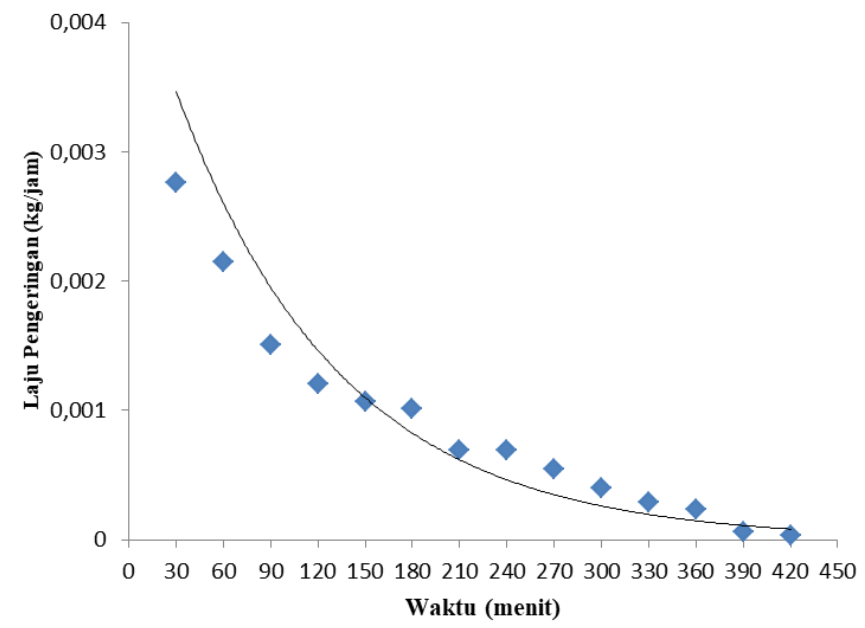

Gambar 5. Pengaruh Waktu Pengeringan terhadap Laju Pengeringan

Pada Gambar 5 dapat dilihat total laju pengeringan keseluruhan mencapai 0,012656 kg/jam $\mathrm{m}^{2}$, dimana laju pengeringan konstan terjadi pada waktu 210 menit hingga 240 menit dengan laju pengeringan sebesar $0,000696 \mathrm{~kg} / \mathrm{jam} \mathrm{m}^{2}$. Perubahan dari laju pengeringan dari laju pengeringan tetap menjadi laju pengeringan menurun untuk bahan berbeda akan terjadi pada kadar air yang berbeda. Laju pengeringan menurun terjadi setelah laju pengeringannya konstan dimana, kadar air bahan lebih kecil daripada kadar air kritis. Penurunan kadar air pada pulp yang dipengaruhi oleh besarnya laju pengeringan yang terjadi selama proses pengeringan 
berlangsung. Terjadinya penurunan laju pengeringan dan cenderung konstan diakhir disebabkan karena kadar air menurun selama proses pengeringan sehingga jumlah air bebas makin lama semakin berkurang dan kadar air pada bahan akan sesuai standar, sehingga laju pengeringan mengalami penurunan dan cenderung konstan. Semakin lama waktu pengeringan kadar air akan menurun, menyebabkan penguapan air lebih banyak sehingga kadar air dalam bahan akan sesuai standar. Pada penelitian ini laju pengeringan akan terus menurun, hal ini sesuai dengan konsep dari laju pengeringan yang ada dimana, laju pengeringan akan menurun seiiring penurunan kadar air yang terjadi selama proses pengeringan [19].

\section{KESIMPULAN}

Dari hasil penelitian yang telah dilakukan menggunakan alat Tray Dryer dengan menentukan waktu dan laju pulp berbasis campuran TKKS dan pelepah pisang dapat disimpulkan bahwa, didapat satu unit alat Dryer tipe Tray dengan panjang 34,5 cm, lebar $35 \mathrm{~cm}$ dan tinggi 39,5 cm dengan kapasitas maksimal $42 \mathrm{~kg}$, memiliki 4 tray, daya heater sebesar 202 watt dan mampu mengeringan pulp dengan sistem pengendalian on - off.

Pada proses pengeringan pulp menggunakan tray dryer dalam mengeringkan pulp berbasis campuran TKKS dan pelepah pisang dengan suhu $60^{\circ} \mathrm{C}$ didapatkan pulp dengan kadar air yang telah sesuai dengan standar kadar air pulp seperti yang telah ditetapkan oleh balai besar pulp sesuai dengan SNI 6106:2016 yaitu sebesar 9,1\% pada waktu pengeringan selama 420 menit dengan laju pengeringan total sebesar $0,012656 \mathrm{~kg} / \mathrm{jam} \mathrm{m}{ }^{2}$

\section{DAFTAR PUSTAKA}

[1] S. Bahri, "Pembuatan Pulp dari Batang Pisang," Jurnal Teknologi Kimia Unimal, vol. 4, no. 2, pp. 36, 2017, https://doi.org/10.29103/jtku.v4i2.72

[2] S. H. Chang, "An overview of empty fruit bunch from oil palm as feedstock for bio-oil production," Biomass and Bioenergy, vol. 62, pp. 174-181, 2014

[3] R. Arjeni, "Pembuatan Pulp Menggunakan Bahan Baku Pelepah Pisang Klutuk dengan Proses Soda," Universitas Muhammadiyah Palembang, 2020

[4] Supraptiningsih. "Pengaruh Serbuk Serat Batang Pisang Sebagai Filler terhadap Sifat Mekanis Komposit PVC-CaCO3,” Majalah Kulit, Karet Dan Plastik, vol. 2 no .28, pp. 79-87, 2012.

[5] S. Y. Prabawati and A. G. Wijaya, "Pemanfaatan Sekam Padi dan Pelepah Pohon Pisang Sebagai Bahan Alternatif Pembuat Kertas Berkualitas,”Jurnal Aplikasi Ilmu-Ilmu Agama, pp. 44-56, 2008.

[6] I. Fariati, "Pengaruh Konsentrasi Larutan Pemasak dan Lama Pemasakan pada Proses Delignifikasi Campuran Pelepah Pisang (Musa Paradisiaca, Linn) dan Tandan Kosong Kelapasawit (Elaeis Guineensis Jac) Untuk Pembuatan Pulp,” In UIN Alauddin Makasar. UIN Alauddin Makasar. 2006.

[7] A. Prasetyo, "Penelitian Pengeringan Ubi Kayu dengan Teknologi Tepat Guna," Universitas Gajah Mada, 2007.

[8] Sugianto and Suhartoyo. "Pemanfaatan Alat Pengering untuk Membantu Industri Pembuat Kertas Souvenir Kulit Pohon Pisang," Universitas Mercu Buana Yogyakarta. 2012

[9] C. J. Geankoplis, "Transport Process and Unit Operations", 3rd ed., Allyn and Bacon Inc., 7 Wells Avenue, Massachussets, 1993

[10] R. B. Kurnia, "Rancang Bangun Alat Pengering Tipe Solar,” Politeknik Negeri Seriwijaya. 2016.

[11] T. A. Makaminan, "Waktu dan Laju Pengeringan Alat Tray Dryer dari Hasil Pembuatan Silika Gel Berbasis Ampas Tebu," Politeknik Negeri Seriwijaya, pp. 1-5. 2019

[12] Badan Standardisasi Nasional. Pulp kraft belum putih kayujarum / Needle Unbleached Kraft Pulp (NUKP) SNI 6106:2016, 2016

[13] Badan Standardisasi Nasional. Cara Uji Kadar Air Pulp dan Kayu dengan Metode Pemanasan dalam Oven, SNI No. 08-7070-2005, 2005

[14] R. E. Treybal, R. E. Mass Transfer Operations, 3th edition. Mc Graw Hill, Inc. 1981

[15] G. Taib, Operasi Pengeringan Pada Pengolahan Hasil Pertanian. PT. Mediyatama Sarana Perkasa, 1988

[16] S. M. Henderson, and R. L. Perry, Agricultural Process Engineering. 3rd ed. The AVI Publ.Co. 1976

[17] S. Amin, P. J. P. Jamaluddin, and M. Rais, "Laju Pindah Panas dan Massa Pada Proses Pengeringan Gabah Menggunakan Alat Pengering Tipe Bak (Batch Dryer)," Jurnal Pendidikan Teknologi Pertanian, vol. 1 , no. 87,2018 
[18] A. Wijaya, "Uji Kinerja Mesin Pengering Tipe Efek Rumah Kaca (ERK) Berenergi Surya dan Biomassa Untuk Pengeringan Biji Pala (Myristica sp.)" di UD SariAwi, Ciherang Pondok, Caringin. IPB. 2007

[19] W. L. McCabe, J. C. Smith, and P. Dave, Scilab Code for Unit Operations of Chemical Engineering Created by Book Details. In Education (Issue October). Mc Graw Hill, Inch, 1993. 